\title{
The Role of Corporate Governance Failure in the Banking Sector
}

\author{
Rezart Dibra, PhD \\ Professional Business Academy, Tirana, Albania
}

doi: 10.19044/esj.2016.v12n34p68 URL:http://dx.doi.org/10.19044/esj.2016.v12n34p68

\begin{abstract}
Corporate governance is the organizational arrangement by which a company represents and serves the interests of its investors. It encompasses anything from a company's boards to executive compensation schemes to bankruptcy laws. Generally, the definitions of corporate governance which was found in the literature tend to share certain characteristics. One of this characteristic is the notion of accountability. Corporate governance is the process of supervision and control which intends to ensure that the company's management acts in accordance with the interests of shareholders (Parkinson, 1994). Corporate governance, the internal policies and leadership that guide the actions of corporations, played a major part in the recent global financial crisis. While much blame has been targeted at compensation arrangements that rewarded extreme risk-taking but did not punish failure, the performance of large, supposedly, sophisticated institutional investors in this crisis have not been examined. Corporate governance has come to the forefront of academic research due to the vital role it plays in the overall health of economic systems. Corporate governance was long ignored as a matter of potential importance for the development of a nation's economy. This paper, however, expresses some cases in the field of corporate governance, regarding the failure of corporate governance. Institutional investors failed to effectively monitor such volatile investments, ignoring relatively well-established corporate governance principles and best practices. Corporate Governance Failures offers nuanced and realistic proposals to mitigate future financial pitfalls.
\end{abstract}

Keywords: Corporate governance (CG), governance failure, transition countries, emerging economies

\section{Introduction}

Corporate governance is the system through which companies are directed and controlled (The Candbury Report, 1992). However, corporate 
governance is a central and dynamic aspect of business. Corporate Governance Failures reveals how these organizations expose themselves and their clientele to extremely complex financial instruments, such as credit default swaps. This is done through investments in hedge and private equity funds as well as more traditional equity investments in large financial institutions. Corporate governance has been practiced since the inception of corporate entities. Corporate governance is the structures, process, cultures, and systems that engender the successful operation of the organization (Keasey \& Wright, 1993). Therefore, corporate governance has become one of the most commonly used phrases in the current global business vocabulary. The notorious collapse of Enron 2001, one of America's largest companies, has focused international attention on company failures and the role that strong corporate governance needs to play to prevent them. "Corporate governance" constitutes a country's private and public institutions, both formal and informal, which together govern the relationship between the people who manage corporations (corporate insiders) and others who invest their resources in various corporations in the country. Consequently, corporate governance generally refers to the set of rule-based processes of laws, policies, and accountability that governs the relationship between the investor (stockholder of a company) and the investee (management). Corporate governance has attracted a great deal of attention in the aftermath of the Asian financial crisis of 1997-1998 and the early 2000s U.S. corporate scandals, like Enron and World Com. However, as soon as the threat of global contagion financial crises passes away, corporate governance was relegated to the background of academic research. The focus of this paper is the challenge that transition countries face in moving from a politically-based relationship to one of a rule-based relationship. It also focuses on the role of corporate governance as a major factor in the unprecedented transformation of transition countries to a market economy.

\section{Models and Principles of Corporate Governance (CG)}

Taking into consideration the many differences between countries all over the globe, corporate governance makes no exception. This is because it is being influenced by culture, history, and politics. Still, we can identify a widely accepted classification of corporate governance models. Thus, these are the market-based system exemplified by the British and American systems and the bank based system from Japan and Germany. The two are also known as “insider/outsider" model, which was studied by Helen Short in 1998. Outsider model or shareholders model, used basically in America or United Kingdom, has a powerful stock exchange which influences the markets all over the world. This system is characterized by effective distancing of ownership and control. Thus, the owners of firm tend to have a 
transitory interest in the firm. In this kind of companies, there is a strong CEO which can easily become the chairman of the board of directors. Also, there a highly dispersed group of shareholders who generally find selling shares to be an easier way of expressing their dissatisfaction with inefficient management rather than creating a change. Insider model or stakeholders' model functions quite different. The owners of the firms tend to have an enduring interest in the company, and the relationships between management and shareholders are close and stable. This system helps the convergence of interests in company but can also result to some major issues such as little or no transparency and abuse of power (especially in family-runned businesses). For instance, in Germany, share ownership is less diffuse and banks play a much more important role as providers of finance. In addition, they monitor the day-to-day activity of financial flow. The company has a very close relationship with its also called Hausbank, a universal bank that owns shares in the company and usually has board representation. Thus, the bank supervises every major step a company takes. Overall, corporate governance in Enron was weak in almost all aspects. The Board of Directors was composed of a number of people who have displayed poor moral character and are willing to conduct fraudulent activity. This was the genuine root of the company's corporate governance failure. There has been a proliferation of books on the downfall of Enron, seeking to explain why events transpired as they did. As we have seen, the USA and the UK reacted strongly to Enron's collapse. In addition, corporate governance has been hurled to centre stage as a result of the weaknesses at the heart of Enron's corporate governance system. The long- term effects of Enron will hopeful result in a cleaner and a more ethical corporate environment across the globe. Therefore, the continuous updating of corporate governance codes of practice and the systematic review of corporate governance checks and balances are necessary to avoid other Enron's in the future. Clearly, corporate governance check and balances can only be used to detect, not cure, unethical practices. A complicating factor in issues of fraud and ethical breakdown is the intangible nature of fraud. Therefore, there is a grey area surrounding what is right or wrong, good or bad in human behaviour. Some comments from Sheldon Zenner and American white-collar criminal and civil lawyer, when speaking of the Enron trial, helped to illuminate this issue. In order to discuss corporate governance, we will establish from the start who are the ones that are responsible for creating and governing the corporation. Corporate governance framework is presented in figure 1. 


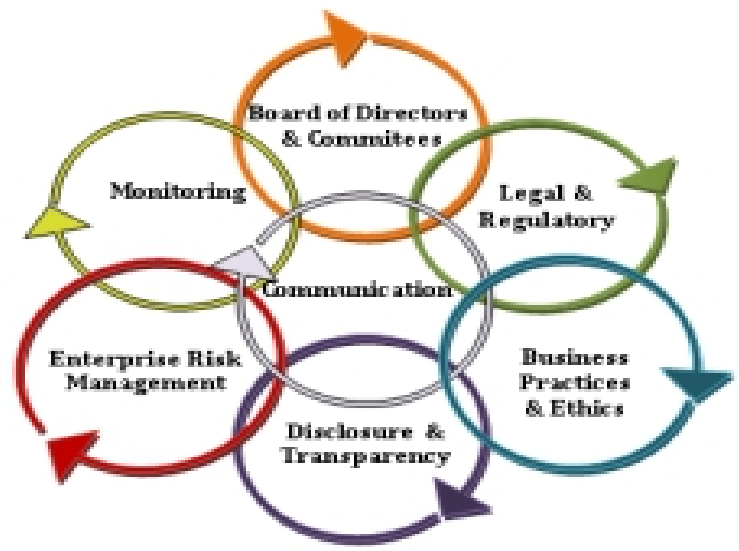

Figure 1. Corporate Governance framework

\section{Corporate Governance (CG) Failure in Enron and Parmalat}

The collapse of Enron during 2001 focused attention on the effectiveness of the non-executive director function. The corporate board, with its mix of expertise, independence, and legal power, is a potentially powerful governance mechanism. Parmalat is a huge and quite well known dairy product company in Italy. It is in charge of almost $50 \%$ of the dairy products in Italy. Parmalat was owned by a complex group of companies which is controlled by one strong blockholder (the founding Tanzi family) through pyramidal structure (see Melis, 2005). Consequently, Melis (1999) explained that such ownership structures with opaque patterns of ownership and control are not uncommon in Italian companies. Melis (2000) stated that the weaknesses of Anglo Saxon systems of corporate governance were traditionally strong managers: strong blockholders and unprotected minority shareholders. The case of Parmalat was typical of this form of corporate governance, with the controlling of Tanzi shareholders channeling corporate resources illegally to themselves, at the expense of minority shareholders (Melis, 2005).

\section{Corporate Governance (CG) Failure in Lehman Brothers}

The corporate governance framework also depends on the legal, regulatory, institutional, and ethical environment of the community. The collapse of Lehman Brothers was the biggest bankruptcy in the corporative history of the USA. It is seen by a lot of people as a corporate governance failure, not a failure of financial markets in September 2008. However, the event resulted to the largest and worst financial crises of the last decades. It became true as a consequence of fatal errors like combination of intricate accounting rules, complex derivatives, greed, excessive leverage, and the complacency of rating agencies. 


\section{Barings Bank}

Although due to the failure of other bank, famous, called the “Queen’s bank”, Baring's story differs from that of Lehman Brothers, a story of a double-dealer who caused the bankruptcy of a supposed solid bank. This case is truly spectacular because for a significant period of time, he managed to conceal his fraudulent concealment of a significant loss. On the $26^{\text {th }}$ of February 1995, the bank Barings Plc, one of the oldest banks of the United Kingdom was declared bankrupt. Nick Leeson, one of the bank traders in Singapore, had lost $\$ 1.4$ billion on derivatives trading while the bank reported capital was only about $\$ 600$ millions. However, this hit came principally from a hit on a long position in the Nikkei 225 futures of notional value around \$7billions on the Osaka and Singapore Exchange. Officially, Nick Leeson was arbitraging the Nikkei 225 futures contracts on the different exchanges. These exchanges include the Singapore International Monetary Exchange (SIMEX) and the Osaka Stock Exchange (OSE). Thus, they purchase the same features at a low price in one exchange and sells simultaneously at a higher price on the other exchange. For Barings London, Nick Leeson was presumably doing a trading strategy with little or no exposure to risk as he was allegedly hedged.

Table 1. Corporative Governance failure (Some cases)

\begin{tabular}{|c|c|c|c|}
\hline No. & Company Name & Country & Observable Causes of Failure \\
\hline 1 & Enron & USA & Inflated earnings \\
\hline 2 & WorldCom & USA & Expenses booked as capital expenditure \\
\hline 3 & Tyco & USA & Looting by CEO, improper share deals \\
\hline 4 & Global Crossing & USA & Inflated corporate profits to defraud investors \\
\hline 5 & Royal Ahold & Netherlands & Earnings overstated \\
\hline 6 & Parmalat & Italy & False transaction recorded \\
\hline 7 & Wal-Mart & USA & $\begin{array}{c}\text { Weaknesses in internal controls have led to } \\
\text { government investigations and class action } \\
\text { lawsuits by employees. }\end{array}$ \\
\hline 8 & & USA & Accelerated revenue recognition \\
\hline
\end{tabular}

(Source: "Reason for Corporate Governance failures ", by Shruti Mehta \& Rachana Srivastvaar)

\section{Conclusion}

Corporate governance is most often viewed as both the structure and the relationships which determine corporate direction and performance. Corporate governance is the organizational arrangement by which a company represents and serves the interests of its investors. Separation of ownership and control in a large stock corporation would be of no particular consequence if the interests of owners and managers coincided. There are, however, reasons to believe that these interests may diverge. It can encompass anything from company boards to executive compensation schemes to bankruptcy laws. Furthermore, a transparent and timely 
communication between those who are involved in decision making process must be the first tool that can prevent cases of failure. The link between information and fraud prevention must go beyond the particular mode of corporate governance chosen, organizational structure, and control mechanisms applied. People are more important than processes. As a result, one of the main goals is to encourage the diffusion of advanced practices which does not only lead to defending the interests of investors, but also to ensure social stability, improving the quality of human capital, and promoting authentic values. Corporate governance mechanisms cannot prevent unethical activity by top management. Thus, they can at least act as a means of detecting such activity by top management before it is too late. Although few of the many cases of corporative governance failures have been treated, we attend to believe that we manage to emphasize the main ideas which involve the interpretation and point of view of the authors. As a solution to eliminate or at least reduce the differences between the three main types of corporate governance, we would see a set of standards and requirements that include features of all types of governance factors, namely an attempt to globalize the management techniques. Therefore, the collapse of corporate governance will be the lesson for all the companies. The financial crisis really got going just about seven years ago and his lessons are important to learn from all the companies around the world according to the corporate governance principles.

\section{References:}

1. Aduda J,Chogii, Magutu, P.O (2013). An empirical test of competiting corporate governance theories.

2. Aguilera V.R \& Jackson G. (2011). Comparative and International Corporate Governance, SSRN.1-73.

3. Anderson, D.W., Melanson S.J., \& Maly, J. (2007). The Evolution of Corporate Governance: power redistribution brings boards to life. Corporate Governance, 15(5):780-797.

4. Agyei A, \& Owusu R A, (2014). The Effect of Ownership Structure and Corporate Governance on Capital Structure of Ghanaian Listed Manufacturing Companies.

5. Arrazola M, \& Hevia J, (2007). “An aggregated index of human capital”, research paper, Economic Bulletin, volume 10 (1), fq 1 -11, URL: http://economics_bulletin.vanderbilt.edu data e aksesit 06.06.2012.

6. Babic, V, Jelena ND \& Jelena EM. (2010) Rethinking Board Role Performance : Toward An Integral Model (1-23).

7. Babić, V. (2010). Corporate Governance In Transition Economics. Ekonomske teme, 34(2), 555,568. 
8. Babić, V.(2003) Corporate governance problems in transition economies, Winston-salem: Wake Forest University, Social Science Research Seminar.

9. Youssef, T (2010). Corporate Governance an overview - around the globe http://www.eiod.org/uploads/Publications/Pdf/Corp.\%20Governance1.pdf.

10. Failure of Corporative Ethics, available online. http://www.mgmtguru.com/mgt499/CorporateEthics.htm 